\title{
Effect Of Organizational Cultures On Lecturers Psychological Empowerment And Organizational Commitment: Structural Equation Modeling Approach
}

\author{
Abubakar Abba Aji ${ }^{1}$ Jamaliah Abdul Hamid ${ }^{2}$ Aminuddin Hassan, ${ }^{3}$ Roziah \\ Mohd Rasdi ${ }^{4}$ \\ University of Maiduguri, Nigeria ${ }^{l}$ \\ Universiti Putra Malaysia, Malaysia ${ }^{2,3} \& 4$
}

\begin{abstract}
Objective: The main objective of this paper is to determine the relationship between organizational cultures and psychological empowerment on organizational commitment among lecturers in Higher Education Institution (HEIs) of Borno State, Nigeria. Organizational culture in this study includes Adhocracy, Market, Hierarchy and Clan cultures.

Methods: Correlational design was adopted using cross sectional approach in this study. Total samples of 417 lecturers were drawn through proportionate random sampling method from a total accessible population of 1287. Data was collected through administration of adapted and adopted instruments from previous researchers designed on 5 point Likert scale. The reliability of the instruments was determined through the pilot study data using Cronbach's alpha reliability coefficients which stands at not less than .93 for all the instruments. The Data was analyzed using Structural Equation Modeling (SEM) with AMOS graphics. Preliminary and subsequent assessments of model fits were conducted from CFA to measurement model which fell within the acceptable threshold, and indicates the data at hand fits the model $\left(\mathrm{x}^{2}(4994)=7873.606, \mathrm{p}=0.00, \mathrm{x}^{2} / \mathrm{df}=1.577\right.$, $\mathrm{GFI}=0.702 ; \mathrm{TLI}=0.901, \mathrm{CFI}=0.906 ; \mathrm{IFI}=0.907, \mathrm{RMSEA}=0.042$ ).
\end{abstract}

Results: Findings depict significant relationship exist between organizational commitment, psychological empowerment, hierarchy and clan cultures. Also there is significant relationship between adhocracy, market, hierarchy and clan cultures with psychological empowerment. Furthermore, psychological empowerment, hierarchy and clan cultures are predictors of organizational commitment in the HEIs examined.

Conclusion: Enhancing organizational culture and psychological empowerment could be a potent mechanism for improving lecturers' organizational commitment in HEIs in Nigeria. Higher educational institutions play critical roles in realizing national socio economic and political aspirations, hence due attention should be given to the types of cultures within organizations that encourage lecturer' sense of psychological empowerment and subsequently their commitment to the organization in specific and education system in general.

KEYWORDS: Higher Educational Institution, Lecturers, Organizational Culture, Organizational Commitment, Psychological Empowerment

\section{INTRODUCTION}

There has been growing attention among Higher Education Institutions (HEI) administrator's in attracting and motivating lecturers within their system. In recent years, internal and external factors such as technological innovations, work conditions, and quality driven management systems have made much impact on human capital development and retention (Jariego, 2015). Organizations have no choice but to change their operational and managerial undertakings to retain their staff and to support and to motivate them to cope and adapt to the change. Many critical sectors such as education, health and management fields have come up with motivational paradigms to uphold employees' organizational commitment as a central determinant to organizational survival (Allen \& Meyer, 1996) and organizational development and growth (Sabella et al,(2016); Meyer and Allen,1997).Nevertheless, organizational commitment literature indicates that there exist a dearth in understanding how organizational factors behave as antecedents influencing commitment. Moreover, literatures of organizational commitment has practically relegated to the background that organizational commitment is essentially contextual (Cohen, 2007). Avolio, Zhu, Koh, \& Bhatia, (2004) and Schneider, 
Ehrhart, \& Macey (2014) argued that organizational structures that include, administration, mission, procedures, policies, staffing, climate, culture and leadership all constituted part and parcel of the context of the organization within which employees work, and which might sensibly influence their level of commitment to the organization. Meanwhile, other researchers such as Pradhan, Panda, \& Jena (2017) have established that, organizational commitment could only be achieved when people personally believe that they are psychologically empowered. Thus, organizational commitment development must take into cognizance both personal and organizational level forces (Cohen, 2007).In accordance to his observation, Cohen (2007) argued that organizational culture ought to be regarded as an organizational level antecedent to organizational commitment; while psychological empowerment as personal level antecedent to organizational commitment. Incidentally, while many researches have revealed a strong relationship between organizational factor and personal factor with organizational commitment; many of these researches however, were in the context of private sectors (Chew and Chan, 2008). Spreitzer (2008) moreover cautioned that the gray attributes of psychological empowerment in terms of its causal effect on different organizational outcomes such as organizational commitments, job satisfaction, job involvement in different organizations from diverse cultural background and settings across the globe makes it worthwhile to investigate the causal and mediating effect of psychological empowerment on employees' commitment to their organization. Seibert, Wang and Courtright (2011) offered a similar observation as Spreitzer's. This present research is conducted in the context of public sectors specifically amongst lecturers in Nigerian public HEIs, and with particular reference to colleges of education, polytechnic and monotechnics. Inclusion of these institutions in research is still scarce in Nigeria, and this is surprising in view of the fact that these institutions have been given statutory HEI status by the government (Baba Gana and Dungus, 2015).

\subsection{RESEARCH QUESTIONS}

The following research questions are formulated to guide the study;

(1) Is there any relationship between organizational culture types with psychological empowerment and lecturer's organizational commitment in HEIs of Borno state?

(2) Which of the organizational culture type has highest predictive ability of organizational commitment in HEIs of Borno state?

\subsection{RESEARCH HYPOTHESIS}

The following Research hypotheses are formulated based on the reviewed literatures.

H1: There is a significant relationship between adhocracy culture and organizational commitment among HEIs lecturers.

H2: There is a significant relationship between market culture and organizational commitment among HEIs lecturers.

H3: There is a significant relationship between hierarchy culture and organizational commitment among HEIs lecturers.

H4: There is a significant relationship between clan culture and organizational commitment among HEIs lecturers.

H5: There is a significant direct contribution of adhocracy culture to organizational commitment.

H6: There is a significant direct contribution of market culture to organizational commitment.

H7: There is a significant direct contribution of hierarchy culture to organizational commitment.

H8: There is a significant direct contribution of clan culture to organizational commitment.

H9: There is a significant relationship between adhocracy culture and psychological empowerment.

H10: There is a significant relationship between market culture and psychological empowerment.

H11: There is a significant relationship between hierarchy culture and psychological empowerment.

H12: There is a significant relationship between clan culture and psychological empowerment.

Ha13: There is a significant relationship between psychological empowerment and organizational commitment among lecturers in HEIs.

H14: There is a direct significant contribution of psychological empowerment to organizational commitment. 


\section{LITERATURE REVIEW}

\subsection{Organizational commitment}

The concept of organizational commitment has become a complex phenomenon due to emergence of diverse standpoint from many scholars, especially in relation to its conceptualization and measurements (Mowday, Porter, \& Steers, 2013). Organizational commitment has been defined in different standpoints, as unidimensional and or multidimensional construct (Allen and Meyer, 1996; Cohen, 2007). According to Powell and Meyer (2004) organizational commitment refers to degree which employees identifies with the organizational goals which is not limited to work process and procedures, and equally resolve to apply effort, take part in processes of decision making in accordance with the values of the organization. Carver and Candela (2008) opined that committed employees are those that demonstrate selflessness to the organization and offer to continue their relationship, putting unparalleled effort to achieve stipulated goals. In another dimension, Meyer and Allen (1991) maintain that employee's psychological connection with their organizations is often viewed in three distinct forms, and each possesses distinctive label. These are affective, continuance and normative commitments. Affective commitment refers to identification, participation and emotional bond to the organization. Employees with affective commitment remain with their organization because they want do so. Continuance commitment signifies "the mindfulness of the expenses or rather cost implication of quitting the organization. Employees whose central relationship is grounded on continuance commitment stay in the organization for the reason that, they need to do so. Normative commitment on the other hands denotes a sense of obligations to remain in the organization. Hence, all the three components of commitment represent varying degrees of employee's association with an organization. Meyer \& Allen (1991) maintained that employees that are fully committed willingly stay with the organization in all situations, and regularly participate in activities, attend to schedules and put maximum economic hours, ensure assets and resources of the organization are secured and share organizational goals. Thus organizational commitment is a psychological and expressive relationship displayed by employees to their organization. We defined psychological empowerment as a state where people feel they are in position to control and direct their own destiny in accomplishing personal and organizational goals. It is often one of the important medium of improving motivation, job satisfaction and organizational commitment (Chang, Shih \& Lin, 2010; Ahadi, 2012). Empowerment promotes skills development through professional growth and increases self-efficacy and reduces employees' turnover. However, it is imperative to note that empowerment in work settings hinges on prevailing culture that is existing in the organization (Ahadi, Suandi, Ismail, \& Omar, 2011).

\subsection{Organizational Culture}

Organizational culture denotes a shared system of belief, feelings, thinking and perception that act as a guide to member's behavior (Schein, 1995; O' Reilly and Chatman, 1996). Organizational culture is one of the organizational level factors influencing employees' commitment and ethical behavior in an organization, their sense of team membership, their performance, self-determination, and retention(Khan \& Rasli, 2015; Kreitner \& Kinicki, 2004). In other words, organizational culture has significant influence on attitudes, behavior and perception of individuals in achieving organizational goals and objectives. Numerous connotations and definitions are put forward by many researchers depending on their taxonomy of organizational culture, the most popular in recent times is that of Cameron and Quinn (1999) which sees organizational culture as what is intrinsically valued by employees, such as the overriding styles of leaderships, the verbal and symbolic procedures and routines, and the definitions of success which define the uniqueness of an organization.

Cameron and Quinn (1999) Competing Values Framework (CVF) consists of two principal dimensions which is then segmentalized into four clusters. CVF initially differentiates between internal and external organizational focus, and secondly, the differentiation between stability and control cultures versus flexibility and discretion cultures. These cultural dimensions ultimately became associated with four culture types namely, clan, adhocracy, market and hierarchy (Cameron \& Quinn, 1999). The four culture types are often seen as related and interwoven with one another. For clarification they are described below:

\subsubsection{The clan culture}

This culture type promotes family orientation in the work place, its emphasis is on accommodative work settings and on teamwork and participation in work process and procedures. In accordance with the type of

DOI: 10.9790/0837-2203037182 $\quad$ www.iosrjournals.org $\quad 73$ |Page


orientation, which is usually participative in nature, generally embracing manager and employees like an extended family, hence it promotes loyalty and commitment (Cameron \& Quinn, 1999). In other words, no form of isolation would be experienced by individuals just so long as people observed strict adherence to obeying the leader and norms, and the supervisor is accepted as the leader with the role of mentoring and facilitation of assigned duties. Team management is the focus. Accordingly, Simamora \& Jerry (2013)and Ghorbanhosseini (2013)found that in clan ideals, there is a high degree of respect for human relation practices and procedures, and in persuading members' organizational commitment.

\subsubsection{The adhocracy culture.}

Adhocracy culture is a type of organizational culture that provides wider opportunities to its employers to nurture and develop innovativeness within the purview of the organizational goals. In other words individuals are encouraged to take risks willingly, to readily accept changes and be inspired to take full control, hence committing themselves to being creative and innovative in solving challenges (Cameron \& Quinn, 1999). According to Inanlou and Ahn (2016) Adhocracy culture was found to have influenced employees' conscious thinking, initiatives to make informed decisions, and having keen awareness of their operating environment. Similar assertion was made by Lok and Crawford, (2004); Harper, (2015), hence adhocracy culture is related to organizational commitment.

\subsubsection{The market culture}

The market culture basically promotes competitiveness, emphasizing winning both from outside and within the organization. The emphasis is on goal achievement and productivity among individuals working in an organization while taking into consideration external forces surrounding the environment (Cameron \& Quinn, 1999). Market culture emphasizes rationalized actions culminating into efficient and productive planning of achieving organizational goal settings. Market culture orientation was found to have influenced organizational commitment through its impact on behaviour pattern of employees in diverse organizations (Yildirim, Acaray and Candan, 2016).Individuals are expected to understand the corporate values and expectations of the organization and the relevance of each and every role, thereby inspiring and motivating employees' commitment in achieving organizational goals (Cameron et al, 2011)

\subsubsection{The hierarchy culture}

This culture type emphasizes rules and regulations in organizations to facilitate consistency in service delivery. The hierarchy culture focuses on internal challenges and pressures, stability, predictability and efficiency (Cameron \& Quinn, 1999). The operating mechanism in the organization is based upon a formal channel of authority that coordinates and directs work flows across all levels (Shurbagi, 2014). Karimi (2016) observed that hierarchy culture gives employees the desired focus to achieve performance. Committed employees are the main drivers in harnessing the organizational inputs to produce output.

The literature on culture types provides insight on how a system operates, and how frictions emerge and are resolved between managers and employees, and between coworkers towards achieving the organizational goals (Ramachandran, et al, 2011). It is pertinent to identify and understand the nature of organizational culture in HEI environment, in specific HEIs in Nigeria, and how culture behaves as an antecedent to organizational commitment amongst lecturers.

\subsection{Relationship between organizational culture and organizational commitment}

Although there are extensive studies from service and related management sectors that have proven organizational culture is significantly related to organizational commitment (Martin, (2010); Acar, (2013), there has been comparatively fewer studies in the context of HEIs (Ahadi, 2012). Organizational commitment has been expressed as in the form of employee compliance to the organization, and this compliance appeared to be associated closely to the culture of power and role identity within the organization. On the other hand, organizational commitment has also been expressed as employees' identification and internalization of organizational values, and is said to be influenced by support and achievement oriented culture (Mohan\& 
Sharma, 2015). The power and role culture map onto the hierarchical and adhocracy culture type of the CVF model, while the support and achievement culture maps onto the clan and market culture types.

Organizational commitment and other positive organizational outcomes are said to be influenced by robust organizational cultures (Laschinger, Finegan, Shamian, \& Wilk, 2004; Liu, 2011; Martin, 2010). Acquah, Seshie, \& Zogbator (2015) reported that prevalent cultures in universities and colleges differs among managerial and faculty staff. Their findings depicted management and faculty have different cultural orientation towards work relation and performance; in other words management's and faculties' belief and attitudes about work in the system differs. In a related study Ramachandran, Chong, and Ismail (2011) found differences in organizational culture types preferred among academics from private and public HEIs. This outcome provides a sharp and strong insight on strategic policy directions on ways and channels on how to appropriately handle organizational culture in public and private HEIs with a view to link lecturer's organizational commitment to achieve predetermined goals and vision of the institutions. In the same vein Aina, Adeyeye, and Ige (2012) reported significant relationship between organizational culture and lecturers commitment in public tertiary institutions. Also, Lim (2010) reported significant relationship between organizational culture and dimensions of organizational commitment (affective, continues and normative commitments). Hence there is sufficient evidence in the literature to support the relationship between organizational culture and organizational commitment.

\subsection{Psychological Empowerment}

The concept of empowerment as a management mechanism has been widely used by many organizations due to its influence in achieving organizational commitment. Many literatures view empowerment from the standpoint of management processes where deliberate and calculated opportunities are offered to employees to feel that they are part of the organization. Empowerment involves helping employees to overcome any sense of powerlessness and to help them achieve personal and organizational goals. Empowerment is a continuous and permanent process aimed at motivating employee to overcome issues related to psychological, structural and cultural elements that negatively affect the behaviours and attitudes of individuals within the context of organizations (Spreitzer, 2008). In more recent times, participative decision making, delegation of authority, and common accessibility to information and organizational resources are regarded as empowering tools inhuman resource management (Gholifar and Gholami, 2014).Spritzer (1997) posited that empowerment in the context of business should be seen in relational and psychological standpoints. Empowerment from the relational standpoint refers to sharing of authority by the hierarchy with other levels within the organization (Spreitzer, 1995). The distribution of authority by managers is aimed to empower the employees, however the resultant effect may be unpredictable, because ultimately it is the employee he or she who chooses to be empowered regardless of whether there were empowering structures put in place in the organization. In a nut shell, empowerment in organizations basically has to do with the employee's mindset or psyche especially in relation to their role in the organization. Many refer to this state of mind as psychological empowerment (Velthouse, 1990, Spreitzer, 2007). The psychological approach identifies intrinsic motivation within the mindset of individuals as the main driver of empowered action, and not those external managerial procedures (Dee et al., 2003). The psychological standpoint considers the employees' personal experience of their work as a unique cultural experience (Vacharakiat, 2008).Spreitzer ( 1995) developed a scale of psychological measurement for empowerment and describe its dimensions as follows: (1) Meaningfulness of task depicting the value a task holds in relation to individual's belief system (2) Competence at task which is a measure to define the extent of skillful demonstration of one's mastery of effectively executing an assigned task (3) Selfdetermination at task which measures the degree or amount of control or autonomy the employee feels over his plans, assignment, responsibilities or behaviors (4) Impact measures the feeling of worth and the degree of confidence that employee has in how his/her activities produce positive organizational outcomes (Chiang \& Hsieh, 2012). In sum, the higher the achievement of scores in each of the above sub-dimensions, the higher the level of psychological empowerment an employee experiences in the organization.

\subsection{Relationship Between organizational culture and psychological empowerment}


Organizational culture plays a significant role in comprehending employee's behaviour and attitudes in organizations. Spreitzer (2007) disclosed that the dominant characteristics of organizational culture such as, values and norms significantly influence organizational commitment. Studies have suggested that different cultures have differently impact on individual's psychological empowerment. Since organizational culture differs from organization to organization (Schneider, Ehrhart \& Macey, 2013), it is necessary to investigate how organizational culture affects psychological empowerment in HEIs Sotisrofki, (2014). As Ahadi et al., (2012) put it, while there are numerous researches on organizational commitment, there are too few studies that established association between organizational culture and psychological empowerment among academics in HEIs. Ahadi's research also reported low, scores in the CVF model components of organizational culture. Their conclusion is that if lecturers are not adequately empowered through a culture whose combined effect ideally ought to facilitate their involvement in decision making, and increase their professional growth and autonomy in actively carrying out their primary role, then much has to be done to motivate lecturers to give their commitment to the aspirations of the HEIs and the nation. Therefore, it is pertinent to provide evidence of the relationship between organizational culture types (adhocracy, market, hierarchy and clan cultures) and their influence on lecturers' psychological empowerment in Nigeria.

\subsection{Relationship between psychological empowerment and organizational commitment}

According to Randolph and Kemery, (2011) challenging work, interacting with interesting individuals, acquiring new skills and getting further opportunity to carry out essential task enhances employee's organizational commitment, empowerment as critical management technique was commonly believe to be key in achieving employees organizational commitment (Allen and Meyer, 1997). Vardi, (2000) argues that strong employee's commitment is often have to do with the realization of organizational assumptions, mission and values are congruent with their anticipations. Conceivably this depicts the meaning dimension of psychological empowerment. Similarly, work of Elloy, (2012) lend support to the above argument suggesting that in line with social exchange Theory (SET) when supervisors displays benevolent act to their employees result in empowerment perception, thus employees tend to reciprocate the gesture with enhance organizational commitment and willingly remain with the organization. Moreover, Jaiswal and Dhar., (2016)opine that, supportive and mentoring role of management have strong effect on employee cognition, because it improves their psychological disposition. The above position is logical, because employee's self-efficacy and autonomy in their task give them great affection to their organization, hence high commitment level. Moreover, empirical evidence depicts that employees support to organizational goals and achievements is been reinforced by extent of psychological empowerment perception (Hanaysha, 2016; Goudarzvandchegini \& Kheradmand, 2013; Baharlou, Yeganeh \& Hashemi, 2016).Furthermore, extant studies evidently confirm both in theory and empirical that there is relationship between psychological empowerment and organizational commitment, researchers in their separate conclusions express the view that highly committed employees feels self-motivated, highly spirited with strong concentration to their assign responsibility (Spreitzer 1995; Thomas and Velthouse, 1990; Rezaie, Saleh, Iman \& Jaafar, 2012; Chan et al., 2015).Inspite the substantial research, not quite much is still known on the relationship between psychological empowerment and organizational commitment in the higher educational context (Ahadi et al, 2012). Thus the previous studies inform the need for the present study to confirm this relationship and fill the gap, since it is proven that, psychological empowerment is an antecedent to employees positive work behaviour such as organizational commitment.

\section{METHODOLOGY}

This paper adopted correlational study using cross sectional method. Using Cochran sample size estimation formula a total sample of 417 lecturers were selected from a total accessible population of 1287 through multi stage sampling technique, where out of the six geo political zones that made up Nigeria, north eastern states were selected as a first cluster, then Borno state was selected as another cluster, again the Higher educational institutions are as well selected as the third cluster, finally proportionate random sampling procedure was adopted in the five (5) HEIs (colleges of education, polytechnic and monotechnics). Data was collected through administration of the adopted questionnaire on 5 point Likert type scale. The questionnaire comprised eighteen (18) items for organizational commitment, 24 items for organizational culture, and 38 items for psychological empowerment. Data analysis was conducted using structural equation modeling (SEM) approach,

DOI: 10.9790/0837-2203037182 www.iosrjournals.org $76 \mid$ Page


where the measurement model and the structural models were tested for good fit. The measurement model was studied to determine the internal consistency (reliability) and the construct validity (discriminant and convergent validity) of the instruments involved in this study. Using confirmatory factor analysis (CFA), the reliability of each item was determined to ensure composite reliability (CR) for each construct. Average Variance Extracted (AVE) was assessed and found to have met the threshold requirement of $>0.5$ depicting high convergent validity. Thus the instruments are valid, reliable and meet up with requirements to measure all the variables involved in this study. The overall measurement model fit was achieved thus, the data fit the model 『x】^2 $(4994)=7873.606, \mathrm{p}=0.00, \llbracket \mathrm{x} \rrbracket{ }^{\wedge} 2 / \mathrm{df}=1.577, \mathrm{GFI}=0.702 ; \mathrm{TLI}=0.901, \mathrm{CFI}=0.906 ; \mathrm{IFI}=0.907, \mathrm{RMSEA}=$ 0.042. Additionally, RMSEA met the cut-off point 0.042 , which is appropriately within range of acceptability.

\section{RESULTS}

\subsection{STRUCTURAL PATH MODEL TESTING}

The Structural Equation Model (SEM) using AMOS graphics was employed to test the entire proposed hypothesis's of the studyas shown in Table 1.

Table 1 Test of the total Effects of Organizational Culture types (IVs) on Psychological Empowerment and Organizational commitment

\begin{tabular}{|l|l|l|l|l|l|l|l|}
\hline $\begin{array}{l}\text { Hypothesized } \\
\text { Relationships }\end{array}$ & & & B & B & S.E. & C.R. & P \\
\hline PS.EMP & $<---$ & ADC & 0.114 & 0.200 & 0.043 & 2.638 & 0.008 \\
\hline PS.EMP & $<--$ & MKC & 0.243 & 0.291 & 0.056 & 4.341 & 0.001 \\
\hline PS.EMP & $<---$ & HRC & 0.083 & 0.131 & 0.041 & 2.039 & 0.041 \\
\hline PS.EMP & $<---$ & CLC & 0.118 & 0.360 & 0.047 & 2.513 & 0.012 \\
\hline OC & $<---$ & PS. EMP & 0.589 & 0.445 & 0.149 & 3.959 & 0.001 \\
\hline OC & $<---$ & ADC & 0.081 & 0.108 & 0.064 & 1.260 & 0.208 \\
\hline OC & $<---$ & MKT & 0.107 & 0.097 & 0.083 & 1.296 & 0.195 \\
\hline OC & $<---$ & HRC & 0.136 & 0.163 & 0.061 & 2.224 & 0.026 \\
\hline OC & $<---$ & CLC & 0.208 & 0.243 & 0.074 & 2.803 & 0.05 \\
\hline
\end{tabular}

Notes: $\mathrm{B}=$ Unstandardized Regression Weight Estimate; SE= Standard Error; Beta= Standardized Regression Weight; $\mathrm{CR}=$ Critical Ration; $\mathrm{P}=$ Significant Alpha; Note: OC: Organizational Commitment, Organizational Culture type-(CLC: Clan culture, ADC: Adhocracy culture, MKC: Market culture, HRC Hierarchy culture), PS. EMP: Psychological empowerment.

In Table 1 , organizational commitment was proven to be significantly associated with hierarchy culture $(\beta=$ $0.163, p=0.026)$, and with clan culture $(\beta=0.243, p<0.05)$. Organizational commitment was not significantly related to adhocracy culture nor to market culture ( $\mathrm{p}>.05)$. On the other hand, all four types of culture were significantly associated with psychological empowerment (adhocracy culture $\beta=0.200, p<0.008$; market culture $\beta=0.291, p<0.05$; hierarchy culture $\beta=0.131, p=0.041$; and clan culture $\beta=0.360, p<0.012$ ). The structural output model indicates that the hypothesized relationship between psychological empowerment and organizational commitment was supported $(\beta=0.445, \mathrm{p}=0.001)$.

Based on the path results of the model in Table 1 , it is proven that on their own neither adhocracy culture nor market culture have direct contributions to organizational commitment (adhocracy $\beta=0.108, \mathrm{CR}=1.260, \mathrm{p}$ $=0.208$; market $\beta=0.097, \mathrm{CR}=1.296, \mathrm{p}=0.195$ ). However hierarchy culture and clan culture both have direct significant paths to organizational commitment (hierarchy $\beta=0.163, \mathrm{CR}=2.224, \mathrm{p}=0.026$; $\operatorname{clan} \beta=0.243, \mathrm{CR}$ $=2.803, \mathrm{p}=0.05)$, and moreover, clan culture seems to contribute the most direct effect to organizational commitment. The structural output model also indicates that psychological empowerment was directly and significantly associated with organizational commitment $(\beta=0.445, \mathrm{CR}=3.959, \mathrm{p}=0.001)$. It was also shown that psychological empowerment acted as a significant factor that mediated between the effects of adhocracy and market culture on lecturers' organizational commitment.

\section{DISCUSSION}


This study was to investigate the relationships between different types of organizational culture and organizational commitment, with psychological empowerment as the mediator. The results indicates that, adhocracy culture and organizational commitment are not significantly related, this is consistent with the finding of Ahadi (2012) who disclosed that adhocracy culture is significantly not related to psychological empowerment and organizational commitment among academics in Malaysian research universities. Hence no direct significant contribution of adhocracy culture to organizational commitment, this might be due to perception of lecturers that more emphasizes was placed by HEIs in creating and acquiring new ideas, resources, outsourcing for innovations, creating tasks, possibilities and opportunities. Generally institutional leaderships seem to illustrate risk taking, creativity and innovations aim at instituting entrepreneurship. However, scares resources couple with bureaucratic and autocratic management practice, with greater paternalistic stewardship in the Nigerian context, such practices and ideologies promoting innovativeness and risk taking could not probably dominate HEIs glaringly as other culture dimensions such as hierarchy and clan culture. The findings of this study supported Ahadi et al., (2012) findings on organizational culture profile of Malaysian research universities which revealed weak adhocracy culture orientation. Furthermore, from the result, it was evident that, hierarchy and clan culture are significantly related to organizational commitment in HEIs in Borno state, this is consistent with work of Beytekin, Yalcinkaya, Dogan and Karakoc (2010) which found that, in Turkish universities hierarchy and market cultures are the most dominant culture orientations, even though, Ahadi and Saundi (2014) reported in their study that hierarchy culture found to be dominant culture but not significantly related with organizational commitment. Ahadi and Saundi (2014) disclose that clan culture type is critical for employees loyalty and organizational commitment and found that clan culture and organizational commitment are significantly related, this suggest that clan culture increases lecturers organizational commitment. Similarly Datuon, (2015) reported that, perception of clan culture among private HEI in Philippines evidently revealed that, there is significant positive relationship between organizational commitment and clan culture and it is the most dominant culture type in the institution, thus organizational commitment is rated high. Earlier Yao et al., (2013) opined that more institutions have realized the many benefits accruing to organizations that institute participatory decision making and mentoring cultural orientation among employees to influence organizational commitment. Similarly, in the Nigerian context, due to extended family orientation, clan culture perception has been a critical factor, therefore their loyalty to the organization is enhanced, thus as the administrator exhibits mentoring role, employees appreciates more and demonstrate commitment by extending their loyalty.

Accordingly, findings from this study depict that, all the types of culture; clan, hierarchical, market and adhocracy are significantly related to psychological empowerment in HEIs. One of the major finding of this paper was that Market culture type was found to be significantly related and unique predictor of psychological empowerment, while psychological empowerment was evidently found to be highest predictor of organizational commitment, followed by clan culture and least predictor was hierarchy culture and are the only culture type that has significant relationship with organizational commitment in HEIs studied. However, market culture that emerged as strongest culture that contributed to psychological empowerment might not be unconnected with the fact that, increasingly lecturers in Nigeria are getting more aware of their task, particularly competitiveness in achieving HEIs goals are the trends in recent years. Generally, HEIs are focusing their orientations towards outcomes reflecting aggressiveness and emphasizing winning as common themes. Lecturers recognize that there is pressure more than ever before in task accomplishment as their institution are outcomes oriented. To this end therefore, it became significant to involved lecturers in the process of decision making, in addition to creating professional development and growth opportunities aimed at increasing their self-efficacy and autonomy to achieve organizational commitment. It may not be out of context to assert that lecturer's professional autonomy is significant factor of psychological empowerment, because lecturers that are autonomous could achieve and do more not only to their career but also to the institutions. Also from the result it was evident that clan culture significantly related to psychological empowerment. This finding is in agreement with Ahadi 2012, which reported that, clan culture is one of the significant predictor of lecturers psychological empowerment, further maintained that same view was expressed by Spreitzer, (1995). In accordance with Ahadi (2012) and Spreitzer (1995) position, the significant relationship between clan culture and psychological empowerment in the Nigeria context could be attributed to recent reforms introduce to the systems where lecturers collaboratively working at various committee levels that serves as some of the decision making mechanism in the HEIs.

\section{CONCLUSION}

This study tried to connect organizational culture (adhocracy, market, hierarchy and clan), psychological empowerment with organizational commitment. Earlier, not much research incorporating these three variables was explored, particularly in the HEIs covering colleges of education, polytechnic and monotechnics in Nigeria. In addition, this study found that psychological empowerment mediates the relationship between clan culture and organizational commitment, so also with hierarchy culture. This underscores the importance of psychological empowerment to lecturer's commitment in HEIs. Organizational 
culture types are found to have not only leading to lecturer's psychological empowerment in HEIs of Borno state, but it is also a critical contextual factor in organizations capable of influencing organizational commitment. However, it was evident that, adhocracy and market culture types are not related to organizational commitment in the study context. This paper evidently captures the significant effect of clan culture on psychological empowerment and organizational commitment, equally confirm was the effect of hierarchy culture and psychological empowerment on organizational commitment. Thus, this study offers theoretical and empirical understanding of the relationship between organizational culture (adhocracy, market, hierarchy and clan) with psychological empowerment on organizational commitment. Therefore the relationship between clan culture and organizational commitment is very important for HEIs administrators and practitioners, so also hierarchy culture with the view to create positive work environment and encouraging high level of organizational commitment among the lecturers, particularly with the contemporary challenges bedeviling higher educational system in relation to acute shortage of qualified lecturers. Albeit this relationship, the role of psychological empowerment is even intense to achieve organizational commitment, since it has proven to be a mediator. Another practical implication for the decision makers in higher educational institutions is to focus on providing harmonious, supportive and mentoring culture that ensures stable rules and regulations in achieving organizational commitment of lecturers to efficiently perform their task. Hence the need for administrators, policy makers to recognize the established significant role of organizational culture types and psychological empowerment play in achieving lecturer's commitments in HEIs. This study has some limitations which would open avenues for future researches. First, the population is limited to only academic working in colleges of education polytechnics and monotechnic in Borno state, Nigeria; therefore it could not be generalized to other institutions of higher learning within the state and Nigeria at large. Future researchers should conduct similar studies in different contexts using these variables under study for possible generalization. Also since the study methodology used was quantitative, future studies may consider qualitative approach to achieve more robust result. To end with, future researchers should examine the effects of other variables on organizational commitment in addition to those that are examined in this study to offer more understanding of their relationship and contribute to existing literature.

\section{REFERENCES}

[1] Acar, A. Z. (2013). The relationships among different organizational culture and leadership types with organizational commitment: A field study on logistics firms. Journal of Business Research-Turk, 5(2), 531 .

[2] Acquah, H. E., Seshie, P. O., \& Zogbator, B. E. (2015). An assessment of the impact of organizational culture on performance from faculty perspective in non-faith based Private university colleges in Ghana.

[3] Ahadi, S., Suandi, T., Ismail, M., \& Omar, Z. (2011). Influence of Organizational Culture on Psychological Empowerment of Academicians in Research Universities. In 12th International conference on HRD Research and Practice Across Europe: Sustaining Growth Through Human Resource Development, University of Gloucestershire, The Park, Cheltenham, UK (pp. 25-27).

[4] Ahadi, S. (2012). Mediating role of psychological empowerment in relationships between structural empowerment and organizational culture, and workplace outcomes among academics in Malaysian research universities (Doctoral dissertation, Universiti Putra Malaysia).

[5] Ahadi, S., \& Suandi, T. (2014). Structural Empowerment and Organizational Commitment: The Mediating Role of Psychological Empowerment in Malaysian Research Universities. Stud, 3(1).

[6] Aina, O., Adeyeye, O. J., \& Ige, A. K. (2012). Organisational Culture and Employees Commitment in Public Tertiary Institutions in Lagos State, Nigeria. European Journal Of Globalization And Development Research, 3(1), 128-142.

[7] Allen, N. J., \& Meyer, J. P. (1996). Affective, continuance, and normative commitment to the organization: An examination of construct validity. Journal of vocational behavior, 49(3), 252-276.

[8] Allen, N. J., \& Meyer, J. P. (1997). Commitment in the workplace: Theory, research and application. Thousand Oaks.

[9] Avolio, B. J., Zhu, W., Koh, W., \& Bhatia, P. (2004). Transformational leadership and organizational commitment: Mediating role of psychological empowerment and moderating role of structural distance. Journal of organizational behavior, 25(8), 951-968.

[10] Babagana, A., \& Dungus, B. (2015). Staff Renumeration and the performance of Ramat Polytechnic Maiduguri Students from 1995 T0 2014. European Journal of Research and Reflection in Management Sciences Vol, 3(5).

[11] Baharlou, M., Yeganeh, M. M., \& Hashemi, S. E. (2016). The mediating role of psychological empowerment and organizational justice in the relationship of servant leadership with job satisfaction, 
organizational citizenship behavior and organizational commitment. International Journal of Behavioral Sciences, 10(3), 99-105.

[12] Beytekin, O. F., Yalçinkaya, M., Doğan, M., \& Karakoç, N. (2010). The organizational culture at the university. International Journal of Educational Researchers, 1(2), 1-13.

[13] ron, K. S., \& Quinn, R. (1999). An introduction to changing organizational culture. Diagnosing and changing organizational culture: Based on the competing values framework, 1-17.

[14] Cameron, K., Mora, C., Leutscher, T., \& Calarco, M. (2011). Effects of positive practices on organizational effectiveness. The Journal of Applied Behavioral Science, 47(3), 266-308.

[15] Carver, L., \& Candela, L. (2008). Attaining organizational commitment across different generations of nurses. Journal of nursing management, 16(8), 984-991.

[16] Chang, L. C., Shih, C. H., \& Lin, S. M. (2010). The mediating role of psychological empowerment on job satisfaction and organizational commitment for school health nurses: A cross-sectional questionnaire survey. International Journal of Nursing Studies, 47(4), 427-433.

[17] Chan, Y. H., Nadler, S. S., \& Hargis, M. B. (2015). Attitudinal and behavioral outcomes of employees'psychological empowerment: a structural equation modeling approach. Journal of Organizational Culture, Communication and Conflict, 19(1), 24.

[18] Chew, J., \& Chan, C. C. (2008). Human resource practices, organizational commitment and intention to stay. International journal of manpower, 29(6), 503-522.

[19] Chiang, C. F., \& Hsieh, T. S. (2012). The impacts of perceived organizational support and psychological empowerment on job performance: The mediating effects of organizational citizenship behavior. International Journal of Hospitality Management, 31(1), 180-190.

[20] Cochran, W. G. (2007). Sampling techniques.John Wiley \& Sons.

[21] Cohen, A. (2007). Commitment before and after: An evaluation and reconceptualization of organizational commitment. Human resource management review, 17(3), 336-354.

[22] Datuon, R. Q. (2015). The Competing Values Framework of Administrators among Private Colleges in the National Capital Region. Journal of Economic Development, Management, IT, Finance, and Marketing, 7(2), 56.

[23] Dee, J. R., Henkin, A. B., \& Duemer, L. (2003). Structural antecedents and psychological correlates of teacher empowerment. Journal of Educational Administration, 41(3), 257.

[24] Elloy, D. (2012). Effects of ability utilization, job influence and organization commitment on employee empowerment: an empirical study. International Journal of Management, 29(2), 627.

[25] Ghorbanhosseini, M. (2013). The effect of organizational culture, teamwork and organizational development on organizational commitment: the mediating role of human capital. Tehnički vjesnik, 20(6), 1019-1025.

[26] Gholifar, E., \& Gholami, H. (2014). The study of affecting factors on faculty members' psychological empowerment: An investigation in the Iran's agricultural colleges. Journal of Applied Research in Higher Education, 6(1), 63-74.

[27] GoudarzvandChegini, M., \& Kheradmand, R. (2013). The relationship between empowerment and organizational commitment. International Research Journal of Applied and Basic Sciences, 4(5), 104756.

[28] Hanaysha, J. (2016). Testing the Effects of Employee Empowerment, Teamwork, and Employee Training on Employee Productivity in Higher Education Sector. International Journal of Learning and Development, 6(1), 164-178.

[29] Harper, C. (2015). Organizations: Structures, processes and outcomes. Routledge.

[30] Inanlou, Z., \& Ahn, J. Y. (2016). The Effect Of Organizational Culture On Employee Commitment: A Mediating Role Of Human Resource Development In Korean Firms. Journal of Applied Business Research (JABR), 33(1), 87-94.

[31] Jaiswal, D., \& Dhar, R. L. (2016). Impact of perceived organizational support, psychological empowerment and leader member exchange on commitment and its subsequent impact on service quality. International Journal of Productivity and Performance Management, 65(1), 58-79.

[32] Jariego, N. (2015). The Mediating Role of Psychological Empowerment Aspects on Transformational Leadership in ZTB Bank.

[33] Kanter, R. M. (1977). Men and women of the corporation. New York: Basic books.

[34] Karimi, O. (2016). Investigating the Relationship between Organizational Culture \& Organizational Performance (Case Study; District 4 Department of Education). Journal of Administrative Management, Education and Training, 12(4), 327-338. 
[35] Khan, M. M., \& Rasli, A. M. (2015). Relationship between organization culture, empowerment and conflict. International Journal of Economics and Financial Issues, 5.

[36] Kreitner, R., \& Kinicki, A. (2004). Organisational Behaviour. 6< sup> th< sup> edition: New York, NY: McGraw-Hill.

[37] Laschinger, H. K. S., Finegan, J. E., Shamian, J., \& Wilk, P. (2004). A longitudinal analysis of the impact of workplace empowerment on work satisfaction. Journal of Organizational Behavior, 25(4), 527-545.

[38] Lim, T. (2010). Relationships among organizational commitment, job satisfaction, and learning organization culture in one Korean private organization. Asia Pacific education review, 11(3), 311-320.

[39] Liu, X. (2011). Corporate culture and corporate governance: Working Paper.

[40] Lok, P., \& Crawford, J. (2004). The effect of organisational culture and leadership style on job satisfaction and organisational commitment: A cross-national comparison. Journal of management development, 23(4), 321-338.

[41] Martin, T. A. (2010). Formal and informal power, access to work empowerment structures, and intent to stay. Ball State University.

[42] Meyer, J. P., \& Allen, N. J. (1991). A three-component conceptualization of organizational commitment. Human Resource Management Review, 1(1), 61-89.

[43] Mohan, V., \& Sharma, D. (2015). Organizational climate in relation to work motivation and organizational commitment: Voice of Research, Interdisciplinary Journal of Contemporary Research in Business, 4 (7), 818.

[44] Mowday, R. T., Porter, L. W., \& Steers, R. M. (2013). Employee-organization linkages: The psychology of commitment, absenteeism, and turnover: Academic press.

[45] OReilly, C. A., \& Chatman, J. A. (1996). Culture as social control: Corporations, cults, and commitment.Research in organizational behavior, vol 18, 1996, 18, 157-200.

[46] Powell, D. M., \& Meyer, J. P. (2004). Side-bet theory and the three-component model of organizational commitment. Journal of Vocational Behavior, 65(1), 157-177.

[47] Pradhan, R. K., Panda, M., \& Jena, L. K. (2017). Transformational Leadership and Psychological Empowerment: Mediating Effect of Organizational Culture in Indian Retail Industry. Journal of Enterprise Information Management, 30(1).

[48] Ramachandran, S., Choy Chong, S., \& Ismail, H. (2011). Organisational culture: An exploratory study comparing faculties' perspectives within public and private universities in Malaysia. International Journal of Educational Management, 25(6), 615-634.

[49] Randolph, W. A., \& Kemery, E. R. (2011). Managerial use of power bases in a model of managerial empowerment practices and employee psychological empowerment. Journal of Leadership \& Organizational Studies, 18(1), 95-106.

[50] Rezaie, D. H., Saleh, P. A., Iman, A. M., \& Jaafar, A. (2012). An analysis of the empowerment level of employees and it's relation to organizational factors. International Journal of Business and Social Science, $3(15)$.

[51] Sabella, A. R., Sabella, A. R., El-Far, M. T., El-Far, M. T., Eid, N. L., \& Eid, N. L. (2016). The effects of organizational and job characteristics on employees' organizational commitment in arts-and-culture organizations. International Journal of Organizational Analysis, 24(5), 1002-1024.

[52] Schneider, B., Ehrhart, M. G., \& Macey, W. H. (2013). Organizational climate and culture. Annual review of psychology, 64, 361-388.

[53] Schein, E. H. (1995). The role of the founder in creating organizational culture. Family business review, $8(3), 221-238$.

[54] Seibert, S. E., Wang, G., \& Courtright, S. H. (2011). Antecedents and consequences of psychological and team empowerment in organizations: a meta-analytic review.

[55] Shurbagi, A. A. M. (2014). The Relationship between Organizational Culture and Organizational Commitment in National Oil Corporation of Libya. In 2nd International Conference on Research in Science, Engineering and Technology (pp. 212-218).

[56] Simamora, B. H., \& Jerry, M. (2013). Current and Preferred Organizational Culture: A Case Study at Private University in Indonesia. International Business Management, 7(4), 353-358.

[57] Sotirofski, K. (2014). Organizational Culture Impact on Psychological Empowerment of Academic Staff. European Journal of Sustainable Development, 3(2), 119-132.

[58] Spreitzer, G. M. (1995). Psychological empowerment in the workplace: Dimensions, measurement, and validation. Academy of management journal, 38(5), 1442-1465.

[59] Spreitzer, G. M. (1995). An empirical test of a comprehensive model of intrapersonal empowerment in the workplace. American journal of community psychology, 23(5), 601-629. 
[60] Spritzer, G., Kiziols, M. A., \& Nason, S. W. (1997). A dimensional analysis of the relationship between psychological empowerment and effectiveness, satisfaction and starin. Journal of Management, 23(5), 679-682.

[61] Spreitzer, G. (2007). Toward the integration of two perspectives: A review of social-structural and psychological empowerment at work. Ann Arbor, 1001, 48109-41234.

[62] Spreitzer, G. M. (2008). Taking stock: A review of more than twenty years of research on empowerment at work. Handbook of organizational behavior, 54-72.

[63] Thomas, K. W., \& Velthouse, B. A. (1990). Cognitive elements of empowerment: An "interpretive" model of intrinsic task motivation. Academy of management review, 15(4), 666-681.

[64] Vacharakiat, M. (2008). The relationships of empowerment, job satisfaction, and organizational commitment among Filipino and American registered nurses working in the USA (Doctoral dissertation).

[65] Vardi, Y. (2000). Psychological empowerment as a criterion for adjustment to a new job. Psychological Reports, 87(3_suppl), 1083-1093.

[66] Yao, Q., Chen, R., \& Cai, G. (2013). How internal marketing can cultivate psychological empowerment and enhance employee performance. Social Behavior and Personality: an international journal, 41(4), 529-537.

[67] Yildirim, S., Acaray, A., \& Candan, B. (2016). The relationship between marketing culture and organizational commitment: An empirical study in Turkey. World Journal of Entrepreneurship, Management and Sustainable Development, 12(1), 66-80. 